\title{
Ability to Participate in Social Roles and Activities Subordinate Domain
}

National Cancer Institute

\section{Source}

National Cancer Institute. Ability to Participate in Social Roles and Activities Subordinate

Domain. NCl Thesaurus. Code C122341.

The collection of PROMIS item scales that assess an individual's perceived ability to perform their usual social roles and activities. 